\title{
Darbepoetin administration to neonates undergoing cooling for encephalopathy: a safety and pharmacokinetic trial
}

\author{
Mariana C. Baserga', Joanna C. Beachy', Jessica K. Roberts' ${ }^{2}$, Robert M. Ward' ${ }^{1,2}$, Robert J. DiGeronimo ', William F. Walsh', \\ Robin K. Ohls ${ }^{4}$, Jennifer Anderson ${ }^{4}$, Dennis E. Mayock ${ }^{5}$, Sandra E. Juul ${ }^{5}$, Robert D. Christensen ${ }^{6}$, Manndi C. Loertscher', \\ Chris Stockmann², Catherine M.T. Sherwin ${ }^{2}$, Michael G. Spigarelli² and Bradley A. Yoder ${ }^{1}$
}

\begin{abstract}
BACKGROUND: Despite therapeutic hypothermia, neonates with encephalopathy (NE) have high rates of death or disability. Darbepoetin alfa (Darbe) has comparable biological activity to erythropoietin, but has extended circulating half-life $\left(t_{1 / 2}\right)$. Our aim was to determine Darbe safety and pharmacokinetics as adjunctive therapy to hypothermia.
\end{abstract}

STUDY DESIGN: Thirty infants $(n=10 / \mathrm{arm}) \geq 36 \mathrm{wk}$ gestation undergoing therapeutic hypothermia for NE were randomized to receive placebo, Darbe low dose $(2 \mu \mathrm{g} / \mathrm{kg})$, or high dose $(10 \mu \mathrm{g} / \mathrm{kg})$ given intravenously within $12 \mathrm{~h}$ of birth (first dose/hypothermia condition) and at $7 \mathrm{~d}$ (second dose/ normothermia condition). Adverse events were documented for 1 mo. Serum samples were obtained to characterize Darbe pharmacokinetics.

RESULTS: Adverse events (hypotension, altered liver and renal function, seizures, and death) were similar to placebo and historical controls. Following the first Darbe dose at 2 and $10 \mathrm{\mu g} / \mathrm{kg}, t_{1 / 2}$ was 24 and $32 \mathrm{~h}$, and the area under the curve $\left(A \cup C_{\text {inf }}\right.$ ) was 26,555 and $180,886 \mathrm{~h}^{*} \mathrm{mU} / \mathrm{ml}^{*}$, respectively. In addition, clearance was not significantly different between the doses $(0.05$ and $0.04 \mathrm{l} / \mathrm{h})$. At $7 \mathrm{~d}, t_{1 / 2}$ was 26 and $35 \mathrm{~h}$, and $A U C_{\text {inf }}$ was 10,790 and $56,233 \mathrm{~h}^{*} \mathrm{mU} / \mathrm{ml}^{*}$, respectively $\left({ }^{*} P<0.01\right)$.

CONCLUSION: Darbe combined with hypothermia has similar safety profile to placebo with pharmacokinetics sufficient for weekly administration.

n developed countries, hypoxic-ischemic encephalopathy (HIE), a known cause of neonatal encephalopathy (NE) occurs in 1 to 3 per 1,000 live term births and remains a serious public health problem with substantial economic and societal burdens $(1,2)$. Many newborns with moderate to severe NE die in the postnatal period, and/or sustain life-long disabilities including significant motor deficits, intellectual and memory impairment, and visual dysfunction $(3,4)$. Therapeutic hypothermia initiated less than $6 \mathrm{~h}$ after birth has become standard of care for newborn infants with moderate or severe NE (5).
Despite hypothermia, death or major neurodevelopmental disability occurs in nearly $40 \%$ of infants with NE $(6,7)$. Therefore, additional neuroprotective strategies are needed. An important area of study includes therapies that may complement the neuroprotective effects of hypothermia and promote neuronal regeneration, recovery, and neurovascular remodeling. Among these therapies, erythropoiesis stimulating agents (ESA; in particular recombinant human erythropoietin or Epo) have been shown to provide neuroprotection, improving short- and long-term neurologic outcome in neonatal animal models of brain injury and NE $(8,9)$. ESA may improve outcomes by mechanisms important in both early and later phases of brain injury following hypoxia-ischemia. These ESA effects include reducing inflammation, limiting oxidative stress, decreasing apoptosis, and promoting angiogenesis and neurogenesis (10-12). Recent small clinical studies suggest that ESA administration after hypoxic-ischemic (HI) injury in newborns not undergoing hypothermia reaches adequate plasma concentrations to improve neurological outcomes without an increase in morbidity $(13,14)$. Darbepoetin alfa (Darbe), an Epo-derived molecule, has an extended circulating half-life and comparable biological activity to Epo, possibly allowing for a sustained therapeutic concentration with a longer dosing interval.

In the present randomized controlled study, we hypothesize that Darbe can be safely administered as an adjunctive therapy to hypothermia to infants $\geq 36 \mathrm{wk}$ gestational age with moderate to severe NE. Based on Darbe pharmacokinetic (PK) studies in premature infants, the current recommendation is to administer Darbe at $4 \mu \mathrm{g} / \mathrm{kg} / \mathrm{dose}$ subcutaneously for the treatment of anemia (15). On the other hand, it has been recently reported that a much higher dose of Darbe $(10 \mu \mathrm{g} / \mathrm{kg} / \mathrm{dose})$ was well tolerated in premature infants. These infants exhibited improved neurodevelopmental outcomes when compared to placebo babies at follow up (16). Based on this background, we elected to study a lower dose of Darbe at $2 \mu \mathrm{g} / \mathrm{kg}$ and a higher dose at $10 \mu \mathrm{g} / \mathrm{kg}$. This phase I study was also designed to determine the PK of Darbe in this population both during the

\footnotetext{
'Division of Neonatology, Department of Pediatrics, University of Utah, Salt Lake City, Utah; ${ }^{2}$ Division of Clinical Pharmacology, Department of Pediatrics, University of Utah, Salt Lake City, Utah; ${ }^{3}$ Division of Neonatology, Department of Pediatrics, Vanderbilt University, Nashville, Tennessee; ${ }^{4}$ Division of Neonatology, Department of Pediatrics, University of New Mexico, Albuquerque, New Mexico; ${ }^{5}$ Division of Neonatology, Department of Pediatrics, University of Washington, Seattle, Washington; ${ }^{6}$ Intermountain Healthcare, McKay Dee Hospital, Ogden, Utah. Correspondence: Mariana C. Baserga (mariana.baserga@hsc.utah.edu) 
time of hypothermia (first dose of Darbe) and after the administration of a second dose of Darbe at $7 \mathrm{~d}$ of life (3-4 d after rewarming). The purpose of studying the PK and safety of a second study dose at $7 \mathrm{~d}$ was to extend the potential neuroprotective effects of Darbe to the reparative phase that follows NE.

\section{RESULTS}

Between October 2012 and December 2013, 62 infants were screened at 8 participating centers. Informed parental consent was obtained for 30 infants, 14 parents declined participation, parents of 8 were unavailable within the limited period for participation, and 10 infants became ineligible during the postinitial screening process ( 7 infants failed to meet criteria for moderate-severe NE, 3 infants had significant congenital anomalies).

\section{Clinical Characteristics}

Twenty-nine infants received whole body cooling and one received head cooling. Baseline maternal, perinatal, and neonatal clinical characteristics were similar in the three groups (Table 1). Twenty infants (67\%) had moderate encephalopathy at the time of screening: 8 in the placebo group, 7 in the

Table 1. Maternal and neonatal characteristics

\begin{tabular}{|c|c|c|c|c|}
\hline & $\begin{array}{l}\text { Placebo } \\
(n=10)\end{array}$ & $\begin{array}{l}\text { Low-dose Darbe } \\
2 \mu \mathrm{g} / \mathrm{kg}(n=10)\end{array}$ & $\begin{array}{l}\text { High-dose Darbe } \\
10 \mu \mathrm{g} / \mathrm{kg}(n=10)\end{array}$ & $\begin{array}{c}\text { Total all patients } \\
\quad(n=30)\end{array}$ \\
\hline \multicolumn{5}{|l|}{ Maternal } \\
\hline Maternal age, years ${ }^{\mathrm{a}}$ & $29(18-35)$ & $30(20-35)$ & $29(21-33)$ & \\
\hline \multicolumn{5}{|l|}{ Complications of pregnancy } \\
\hline Antepartum hemorrhage, $n(\%)$ & 2 & 0 & 1 & $3(10)$ \\
\hline Pre-eclampsia, $n(\%)$ & 3 & 0 & 0 & $3(10)$ \\
\hline Rupture of membranes $>18 \mathrm{H}-\mathrm{n}(\%)$ & 0 & 2 & 0 & $2(7)$ \\
\hline \multicolumn{5}{|l|}{ Intrapartum complications } \\
\hline Fetal heart rate decelerations, $n(\%)$ & 8 & 8 & 10 & $26(87)$ \\
\hline Cord prolapse-n (\%) & 0 & 2 & 0 & $2(7)$ \\
\hline Placental problems: abruption, previa, $n(\%)$ & 3 & 2 & 4 & $9(30)$ \\
\hline Uterine rupture, $n(\%)$ & 1 & 0 & 3 & $4(13)$ \\
\hline Emergency cesarean delivery, $n(\%)$ & 6 & 7 & 7 & $20(67)$ \\
\hline Vacuum/forceps delivery, $n$ (\%) & 2 & 2 & 1 & $5(17)$ \\
\hline \multicolumn{5}{|l|}{ Neonatal } \\
\hline Age at randomization, hours ${ }^{\mathrm{a}}$ & $6(5-9)$ & $8(2-11)$ & $7(2-10)$ & $7(2-11)$ \\
\hline Transferred from birth hospital, $n(\%)$ & 5 & 4 & 6 & $15(50)$ \\
\hline Gestational age, weeks ${ }^{\text {a }}$ & $38(36-41)$ & $39(36-41)$ & $39(37-40)$ & $39(36-41)$ \\
\hline Birth weight $(\mathrm{g})^{\mathrm{b}}$ & $3,093 \pm 388$ & $2,892 \pm 440$ & $3,042 \pm 390$ & $3,009 \pm 401$ \\
\hline Male sex, $n(\%)$ & 4 & 5 & 6 & $15(50)$ \\
\hline \multicolumn{5}{|l|}{ Apgar score $(\leq 5)-\mathrm{n}(\%)^{\mathrm{a}}$} \\
\hline 5 Min & 8 & 8 & 8 & $24(80)$ \\
\hline $10 \mathrm{Min}$ & 6 & 8 & 7 & $21(70)$ \\
\hline Positive pressure/intubation in delivery room, $n(\%)$ & 8 & 5 & 10 & $23(77)$ \\
\hline Chest compressions at delivery, $n(\%)$ & 7 & 4 & 6 & $17(57)$ \\
\hline Epinephrine, $n(\%)$ & 4 & 2 & 4 & $10(33)$ \\
\hline \multicolumn{5}{|l|}{ Cord blood (arterial or venous) $^{\mathrm{a}}$} \\
\hline $\mathrm{pH}$ & $7.00(6.60-7.3)$ & $7.00(6.70-7.20)$ & $7.20(6.80-7.30)$ & $7.00(6.60-7.30)$ \\
\hline Base deficit-mEq/liter & $18(7-27)$ & $13(7-28)$ & $11(5-26)$ & $14(5-28)$ \\
\hline \multicolumn{5}{|l|}{ Blood gas within 60 min of age ${ }^{a}$} \\
\hline $\mathrm{pH}$ & $7.20(6.60-7.30)$ & $7.00(6.60-7.20)$ & $7.10(6.70-7.30)$ & $7.00(6.60-7.30)$ \\
\hline Base deficit-mEq/liter & $14(4-30)$ & $15(12-21)$ & $17(8-34)$ & $15(4-34)$ \\
\hline Moderate encephalopathyc & 8 & 7 & 5 & $20(67)$ \\
\hline Severe encephalopathy ${ }^{c}$ & 2 & 3 & 5 & $10(33)$ \\
\hline Seizures ${ }^{c}$ & 2 & 3 & 1 & $6(20)$ \\
\hline Target cooling temperature achieved, hours ${ }^{\mathrm{a}}$ & $3(1-4)$ & $3(3-4)$ & $3(3-4)$ & $3(1-4)$ \\
\hline
\end{tabular}

${ }^{a}$ Median (range). ${ }^{b}$ Mean \pm SD. ${ }^{c}$ Data are for these characteristics at time of randomization. 
low-dose Darbe group, and 5 in the high-dose Darbe group. Ten infants had severe encephalopathy on exam: 2 in the placebo group, 3 in the low-dose Darbe group, and 5 in the high-dose Darbe group. Six infants had seizures at the time of screening: 2 in the placebo group, 3 in the low-dose Darbe group, and one in the high-dose Darbe group.

\section{Adverse Events}

As shown in Table 2, there were two deaths within the first week of life ( $n=1$ placebo and $n=1$ low-dose Darbe). Both deaths were associated with multi-organ failure and were not attributed to study participation. No other SAEs were reported. Other AEs were similar between all three study groups (Table 2). The most commonly noted AEs in all of the groups included: hypotension, altered renal function, and pulmonary hypertension. No patients were found to have polycythemia, neutropenia, or sepsis. Feeding difficulties and anticonvulsant therapy for seizures at the time of discharge were similar between the study groups.

Table 2. Adverse events

\begin{tabular}{lccc}
\hline Adverse events & $\begin{array}{c}\text { Placebo } \\
(n=10)\end{array}$ & $\begin{array}{c}\text { Low-dose Darbe } \\
2 \mu \mathrm{g} / \mathrm{kg}(n=10)\end{array}$ & $\begin{array}{c}\text { High-dose Darbe } \\
10 \mu \mathrm{g} / \mathrm{kg}(n=10)\end{array}$ \\
\hline $\begin{array}{l}\text { Death in first month } \\
\text { of life }\end{array}$ & 1 & 1 & 0 \\
$\begin{array}{l}\text { Hypotension } \\
\text { a }\end{array}$ & 4 & 4 & 4 \\
$\begin{array}{l}\text { Cardiac arrhythmias } \\
\text { Pulmonary } \\
\text { hypertension }\end{array}$ & 1 & 0 & 1 \\
$\begin{array}{l}\text { Altered renal } \\
\text { function }\end{array}$ & 1 & 3 & 2 \\
$\begin{array}{l}\text { Altered hepatic } \\
\text { function }\end{array}$ & 3 & 6 & 3 \\
$\begin{array}{l}\text { Thrombocytopenia } \\
\begin{array}{l}\text { Seizures } \\
\text { d }\end{array}\end{array}$ & 1 & 1 & 2 \\
$\begin{array}{l}\text { Discharge status } \\
\quad \begin{array}{l}\text { Gavage feedings/ } \\
\text { G-tube }\end{array}\end{array}$ & 3 & 2 & 2 \\
$\begin{array}{l}\text { Seizures requiring } \\
\text { anticonvulsants }\end{array}$ & 1 & 2 & 2 \\
\hline
\end{tabular}

aHypotension was defined as systolic blood pressure $\leq 50 \mathrm{mmHg}$ requiring inotrope support. ${ }^{b}$ Altered renal function was defined as urine output $<0.5 \mathrm{ml} / \mathrm{k} / \mathrm{h}$ for $>24 \mathrm{~h}$ or serum creatinine $>1.5 \mathrm{mg} / \mathrm{dl}$. ' Altered hepatic function was defined as aspartate aminotransferase (AST) > 200 IU/l and/or alanine aminotransferase (ALT) >100 IU/I. ${ }^{\mathrm{d} A f t e r}$ first study dose.

\section{MRI Results}

A total of 27 brain magnetic resonance imaging (MRI) studies (one per subject, 9 in each study group) performed at a median of $12 \mathrm{~d}$ (range 3-23) were scored by a central reader. Two patients died before a brain MRI was obtained. One patient family (high-dose Darbe group) could not be reached to obtain consent to review the MRI by a central reader. The overall global scores are depicted by study group in Table 3. The majority of infants had either a normal or mildly affected MRI. Seven infants had a subdural hematoma, and none had evidence of sinovenous thrombosis.

\section{Pharmacokinetic Results}

Of the 30 patients enrolled, 27 had data available for first-dose pharmacokinetic analyses (one patient died and did not have sufficient pharmacokinetic data to contribute, one received the first dose after two protocol-defined temperature deviations, and one did not receive the first dose within the first $12 \mathrm{~h}$ of life). The noncompartmental pharmacokinetic parameters associated with the first dose of Darbe are presented in Table 4. The Darbe $\mathrm{AUC}_{\text {inf }}$ and the $C_{\max }$ were significantly higher for the $10 \mu \mathrm{g} / \mathrm{kg}$ group than for the $2 \mu \mathrm{g} / \mathrm{kg}$ group ( $P=0.01$ and $P=0.03$, respectively). There were no significant differences in the terminal elimination half-life $\left(t_{1 / 2}\right)$, the clearance $(\mathrm{CL})$, or the mean residence time between the two treatment groups. Evaluating linearity of the PK after the first dose by plotting log $\left(\mathrm{AUC}_{\mathrm{inf}}\right)$ vs. log (dose) indated a slope of 0.86, suggesting nonlinearity. Figure 1 depicts the difference in Epo serum concentration over time among the high-dose Darbe, low-dose Darbe, and placebo groups following the first study dose.

Among the 28 infants surviving to $7 \mathrm{~d}$ who received the second Darbe dose, 23 had available data for PK analyses (4 infants did not receive the second dose, one due to planned surgery, two due to prior discharge from the neonatal intensive care unit and one due to discontinuation of study drug for an adverse event (thrombocytopenia); additionally, one infant was excluded because the first Darbe dose was given $>12 \mathrm{~h}$ after birth). The noncompartmental pharmacokinetic parameters for the second dose of Darbe are also presented in Table 4. Results were similar to those observed after the first dose. The $\mathrm{AUC}_{\text {inf }}$ was lower for the $2 \mu \mathrm{g} / \mathrm{kg}$ dose as compared to the 10 $\mu \mathrm{g} / \mathrm{kg}$ dose $(P=0.003)$, with no difference detected for the $t_{1 / 2}$ or the mean residence time.

Complete urine data were available for 13 patients. The median (interquartile range) Epo $\mathrm{AURC}_{0-24}$ was not significantly different: $1,195(797-9,799) \mathrm{ml}^{*} \mathrm{mU} / \mathrm{ml}$ for the

Table 3. Brain MRI results

\begin{tabular}{lcccc}
\hline MRI global score & $\begin{array}{c}\text { Placebo } \\
(n=9)\end{array}$ & $\begin{array}{c}\text { Low-dose Darbe } \\
2 \mu \mathrm{k} / \mathrm{kg}(n=9)\end{array}$ & $\begin{array}{c}\text { High-dose Darbe } \\
10 \mu \mathrm{g} / \mathrm{kg}(n=9)\end{array}$ & $\begin{array}{c}\text { All patients } \\
(n=27)(\%)\end{array}$ \\
\hline Normal (score $=48), n$ & 3 & 4 & 3 & $10(37)$ \\
Mild injury (score $=49-59), n$ & 2 & 4 & 2 & $9(33)$ \\
Moderate injury (score $=60-80), n$ & 4 & 1 & 1 & $7(25)$ \\
Severe injury (score $>81), n$ & 0 & 0 & $1(4)$
\end{tabular}


Table 4. Darbe PK following the first and second study doses

\begin{tabular}{|c|c|c|c|}
\hline & $\begin{array}{c}\text { Low-dose } \\
\text { Darbe } 2 \mu \mathrm{g} / \mathrm{kg} \\
\text { (median, IQR) }\end{array}$ & $\begin{array}{l}\text { High-dose Darbe } \\
\text { Darbe } 10 \mu \mathrm{g} / \mathrm{kg} \\
\text { (median, IQR) }\end{array}$ & $\begin{array}{c}P \\
\text { value }\end{array}$ \\
\hline \multicolumn{4}{|l|}{ Darbe first dose } \\
\hline$A U C_{\text {inf }}\left(h^{*} m U / m l\right)$ & $\begin{array}{c}26,555 \\
(20,049-35,029)\end{array}$ & $\begin{array}{c}180,886 \\
(146,568-199,680)\end{array}$ & 0.006 \\
\hline$t_{1 / 2}(\mathrm{~h})$ & $\begin{array}{c}24 \\
(20-28)\end{array}$ & $\begin{array}{c}32 \\
(23-58)\end{array}$ & 0.145 \\
\hline MRT (h) & $\begin{array}{c}34 \\
(29-40)\end{array}$ & $\begin{array}{c}46 \\
(32-83)\end{array}$ & 0.145 \\
\hline $\mathrm{CL}(\mathrm{l} / \mathrm{h})$ & $\begin{array}{c}0.05 \\
(0.03-0.06)\end{array}$ & $\begin{array}{c}0.04 \\
(0.03-0.05)\end{array}$ & 0.665 \\
\hline$C_{\max }(\mathrm{mU} / \mathrm{ml})$ & $\begin{array}{c}1,220 \\
(1,013-6,468)\end{array}$ & $\begin{array}{c}6,309 \\
(3,670-6,468)\end{array}$ & 0.027 \\
\hline \multicolumn{4}{|l|}{ Darbe second dose } \\
\hline$A U C_{i n f}\left(h^{*} m U / m l\right)$ & $\begin{array}{c}10,790 \\
(7,043-13,493)\end{array}$ & $\begin{array}{c}56,233 \\
(54,915-71,260)\end{array}$ & 0.003 \\
\hline$t_{1 / 2}(\mathrm{~h})$ & $\begin{array}{c}26 \\
(23-33)\end{array}$ & $\begin{array}{c}35 \\
(26.5-41)\end{array}$ & 0.414 \\
\hline MRT (h) & $\begin{array}{c}37 \\
(33-48)\end{array}$ & $\begin{array}{c}51 \\
(38-59)\end{array}$ & 0.414 \\
\hline
\end{tabular}

$A \cup C_{\text {inf }}$ area under the curve, extrapolated to infinity; $C_{\text {max }}$ maximal concentration; MRT, mean residence time; $t_{1 / 2}$, terminal half-life. placebo-treated group $(n=3), 3,109(2,211-6,029) \mathrm{ml}^{*} \mathrm{mU} / \mathrm{ml}$ for the $2 \mu \mathrm{g} / \mathrm{kg}$ Darbe-treated group $(n=4)$, and 6,643 $(1,508$ $19,654)$ for the $10 \mu \mathrm{g} / \mathrm{kg}$ Darbe-treated group $(n=6)$.

Limited data were available to characterize the penetration of Darbe into the cerebrospinal fluid (CSF). Two patients (one in the $2 \mu \mathrm{g} / \mathrm{kg}$ treatment group and one in the $10 \mu \mathrm{g} / \mathrm{kg}$ treatment group) had a lumbar puncture performed during the study period. CSF and plasma were obtained from each of these patients to compare the relative concentrations of Darbe. The patient in the $2 \mu \mathrm{g} / \mathrm{kg}$ treatment group had a CSF: plasma ratio of 0.059 (5.9\%) $23 \mathrm{~h}$ after dosing. The patient who received $10 \mu \mathrm{g} / \mathrm{kg}$ of Darbe had a CSF: plasma ratio of 0.027 (2.7\%) $17 \mathrm{~h}$ after dosing.

\section{DISCUSSION}

This is the first clinical report characterizing the safety and pharmacokinetic properties of Darbe when used as an adjunctive therapy to hypothermia in critically ill infants with moderate-severe NE of a hypoxic-ischemic origin. Importantly, no SAEs were ascribed by the investigators and data and safety monitoring board (DSMB) to the Darbe treatment. The incidence of comorbidities or AEs in these critically ill infants was similar to the placebo group and historical controls (5). The pharmacokinetic analysis in the present study shows that highdose Darbe administered once during hypothermia and again

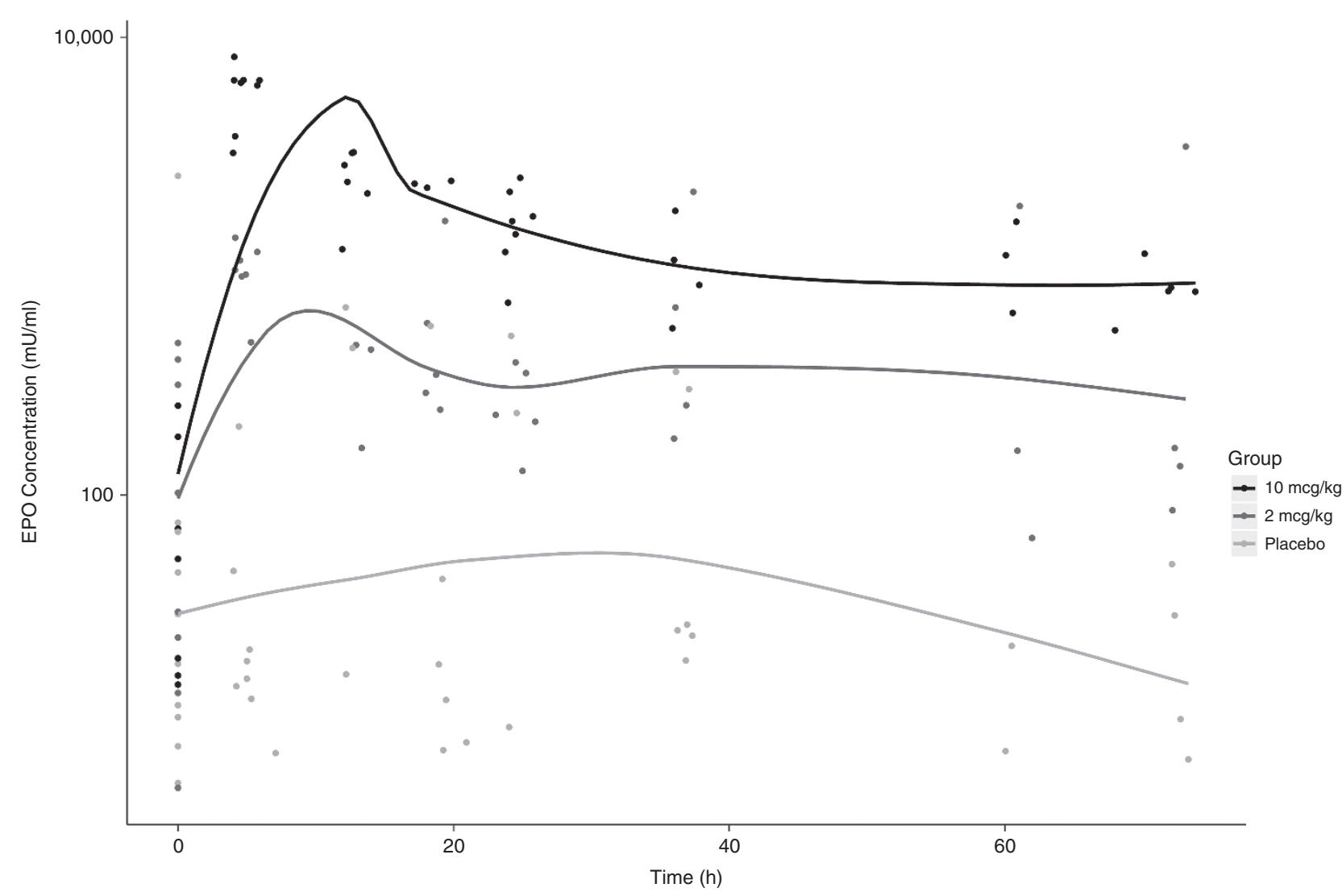

Figure 1. Mean serum Epo concentrations over time measured in infants who received Darbe high dose (10 $\mu \mathrm{g} / \mathrm{kg} \mathrm{IV}$, black diamond), Darbe low dose ( $2 \mu \mathrm{g} / \mathrm{kg}$ IV, dark grey diamond), or placebo (normal saline, light grey diamond) in conjunction with hypothermia. Darbe followed nonlinear pharmacokinetics. 
$7 \mathrm{~d}$ later was well tolerated and achieved plasma concentrations that allow for weekly dosing.

In recent years, ESA have been studied extensively in preclinical trials of neuroprotection prompted by the finding that Epo receptors are expressed in a variety of cells types throughout the fetal and neonatal brain including astrocytes, oligodendrocytes, microglia, and endothelial cells $(17,18)$. Both Epo and Darbe administered intravenously can cross the blood-brain barrier in amounts that can account for their neuroprotective actions (19).

Animal models of perinatal brain injury have demonstrated that Epo improves histological and functional recovery associated with activation of cellular mechanisms that inhibit apoptosis and promote cell maturation, neurovascular remodeling, revascularization, and neurogenesis $(10,11,20,21)$. Recently, Traudt et al. showed, in a nonhuman primate model of HIE, that Epo combined with hypothermia decreased death and moderate/severe cerebral palsy in comparison to placebo or hypothermia only. Additionally, neuroimaging studies were improved with combined Epo/hypothermia treatment (9). Similar to the preclinical trials with Epo, Darbe administration following cortical impact injury in neonatal rats improved cerebrovascular function and reduced histological damage in a dose- and time-dependent manner (22). Weekly administration of Darbe conferred histological and behavioral neuroprotection after intracerebral hemorrhage in rats similar to that of Epo administration (8). Finally, following focal cerebral ischemia in rats (middle cerebral artery occlusion), Darbe-treated rats had decreased infarct volume with improved neurologic scores relative to vehicle-treated animals (23).

The first goal of the present study was to evaluate the safety of Darbe when used as an adjunctive therapy to hypothermia. Despite more than $20 \mathrm{y}$ of use, few safety concerns have been identified with the use of ESA in newborn term and preterm infants. The more common complications of prolonged ESA treatment in adults such as polycythemia, seizures, hypertension, stroke, myocardial infarction, tumor progression, and death have not been reported in Epo- or Darbe-treated neonates $(15,16,24)$. Wu et al. (25) evaluated the safety of escalating Epo doses in 24 patients with NE undergoing hypothermia and found no safety concerns.

There were two deaths in our study before $5 \mathrm{~d}$ of life (one each in the placebo and the low-dose Darbe group) that were attributed to multiorgan failure secondary to severe perinatal asphyxia. No other SAEs were encountered. The overall incidence of comorbidities or adverse events in these critically ill newborn infants was similar among the three study groups, and did not differ from historical controls that received hypothermia alone (5).

The second objective of this study was to establish the pharmacokinetic profile of Darbe as an adjunctive therapy to hypothermia in the treatment of neonates with encephalopathy. Measuring the concentrations of Epo in the placebo group provided the unique opportunity to evaluate the relative contributions of Darbe and endogenous Epo in the total Epo concentration measured for each patient. This was important since the ELISA used to measure Darbe cross reacts with Epo. The median half-life of Darbe was greater in the high-dose group (31.8 and $35 \mathrm{~h}$ following the first and second Darbe dose, respectively) when compared to the low-dose group (23.5 and $25.6 \mathrm{~h}$ following the first and second Darbe doses, respectively) but did not reach statistical significance between the two treatment groups. This is most likely due to the wide range in severity of illness and low sample number. Our findings are similar to the half-lives reported in a study of 11 adults who received a bolus of $100 \mathrm{U} / \mathrm{kg}$ of Epo and an equivalent peptide mass of Darbe intravenously $\left(t_{1 / 2}=25.3 \mathrm{~h}\right)(26)$. Those half-lives were 2.5 times longer than those from Darbe-treated premature infants $\left(t_{1 / 2}=10.1 \mathrm{~h}\right)(27)$. The infants in the present study received hypothermia for $72 \mathrm{~h}$ when the first study dose was given and had a substantial hypoxic-ischemic episode, both of which might have affected the pharmacokinetics of Darbe. Additionally, studies in sheep have shown that clearance of Epo is age dependent, demonstrating quicker clearance in preterm lambs compared to term lambs and adults (28).

The $\mathrm{AUC}_{\text {inf }}$ of the $2 \mu \mathrm{g} / \mathrm{kg}$ group and the $10 \mu \mathrm{g} / \mathrm{kg}$ group were statistically different. This was expected due to the difference in the amount of drug administered in each of the treatment groups. The $\mathrm{AUC}_{\text {inf }}$ differed significantly when comparing the first and second dose of each treatment group, with the $\mathrm{AUC}_{\text {inf }}$ among the $2 \mu \mathrm{g} / \mathrm{kg}$ group decreasing by $60 \%$ and the $\mathrm{AUC}_{\text {inf }}$ among the $10 \mu \mathrm{g} / \mathrm{kg}$ group decreasing by $\sim 70 \%$. This could be attributed to the difference in core body temperatures between the two dosing states since the first dose was administered under hypothermic conditions. Alternatively, the difference could be attributed to developmental changes over the 7-d period between doses. Epo studies in sheep have indicated developmental differences in the pharmacokinetics between fetal, newborn, and adult lambs (29). However, it must be noted that the first plasma concentration obtained after administering the second dose occurred between $12-18 \mathrm{~h}$ after dosing, which may underestimate the $\mathrm{AUC}_{\text {inf }}$ for the second dose. As such, consideration of the study design is warranted before attempting to make direct comparisons between the two doses for each treatment group.

Endogenous Epo is primarily eliminated by receptor-mediated uptake mechanisms, mainly via receptors on progenitor cells (30-31). Though the evidence for Darbe elimination by progenitor cells is not as substantial as that for Epo, Darbe elimination may follow similar pathways (32). In the present study, there was no significant difference between either treatment group in the $\mathrm{AURC}_{0-24}$, relative to the placebo-treated group, most likely due to the relatively small number of infants evaluated and wide between subject variability. It is intriguing, though, that the high-dose Darbe recipients had a median AURC $_{0-24}$ almost six times higher and two times higher than the placebo and low-dose group, respectively. Warwood et al. (33) quantified Darbe clearance in the urine after subcutaneous and intravenous administration in premature infants and found no difference between the two modes of administration with negligible detectable urinary Epo. However, we infused Darbe at a much faster rate $(5 \mathrm{~min})$ than Warwood et al. $(4 \mathrm{~h})$ 
did, perhaps achieving a much higher peak serum concentration and leading to higher urine loss. The results of this study suggest a possible role of renal excretion as a route of elimination for high dose Darbe when given at a fast rate IV.

CSF was obtained from only two patients in the study as part of their routine medical care. Comparing the CSF to plasma concentrations, CSF: plasma ratios ranged from 2.7 to $5.9 \%$ from 17 to $23 \mathrm{~h}$ after dosing. No placebo patients had a lumbar puncture performed during the study period, thus it is unclear whether measured concentrations were reflective of endogenous erythropoietin or Darbe. Nevertheless, these concentrations are similar to the CSF: plasma ratios documented in neonatal patients with NE treated with recombinant Epo (1.0-9.1\% at 1 to $23 \mathrm{~h}$ post-Epo dose) (25).

One of the goals of this trial was to determine an appropriate dose and interval administration for use in future studies. This study showed that the $10 \mu \mathrm{g} / \mathrm{kg}$ dose produced a median $\mathrm{AUC}_{\text {inf }}$ of $180,886 \mathrm{~h}^{*} \mathrm{mU} / \mathrm{ml}$ after the first dose, which is comparable to the range of $\mathrm{AUC}_{\text {inf }}$ values previously reported to correlate with neuroprotection in rats (117,677-140,331 $\mathrm{h}^{\star} \mathrm{mU} / \mathrm{ml}$ ) (34). The median half-life of Darbe also achieved results that support weekly dosing due to its prolonged action and high biological activity.

There are a few limitations to this study. First, due to the small number of participants, infrequent adverse events may not be detected. There was also lack of long-term follow-up to assess long-term safety concerns. Secondly, levels of Epo in CSF remain uncertain since only two patients underwent a lumbar puncture and no placebo-treated infants had CSF available.

Similarly, the urine Darbe PK results are limited by the low number of subjects in which we were able to obtain urine in the first $24 \mathrm{~h}$. Future measurements are needed to further elucidate the extent of renal Darbe excretion in these patients. Lastly, it is still unclear what constitutes a "neuroprotective" Epo serum level in the human newborn with NE following a hypoxic-ischemic event. This emphasizes the need for large randomized clinical trials that are powered to define Epo and Darbe pharmacokinetic thresholds that are associated with improved neurological outcomes.

\section{Conclusion}

Our results demonstrate that Darbe used as adjunctive therapy to hypothermia in the first $12 \mathrm{~h}$ of life and repeated at $1 \mathrm{wk}$ of life has similar safety profile to placebo with pharmacokinetics sufficient for weekly administration.

The vulnerability to brain injury in term infants with $\mathrm{NE}$ extends beyond the first few days of life. Darbe has the potential to positively affect both acute and chronic aspects of brain injury and repair while offering the advantage of an extended half-life and weekly dosing. A future efficacy trial is warranted to determine whether high dose Darbe in combination with hypothermia can further reduce mortality and the risk of longterm disabilities in infants with moderate or severe NE.

\section{METHODS}

This multicenter placebo-controlled, randomized, blinded, multidose pharmacokinetic and safety trial included 30 infants $(n=10$ in each arm) at least $36 \mathrm{wk}$ gestation with moderate to severe HIE undergoing hypothermia at eight centers: University of Utah Hospital $(N=6)$; Primary Children's Hospital $(N=4)$; Intermountain Medical Center $(N=8)$; Monroe Carell Jr Children's Hospital at Vanderbilt $(N=6)$; University of New Mexico Children's Hospital $(N=1)$ and Presbyterian Hospital $(N=3)$; Seattle Children's Hospital $(N=1)$; and McKay Dee Hospital-Intermountain Healthcare $(N=1)$. The study received institutional review board approval at the eight participating hospitals and was registered with clinicaltrials.gov (identifier NCT01471015) and the US Food and Drug Administration (FDA) (Investigational New Drug 113284).

\section{Patient Selection}

Infants were eligible for the Darbepoetin administration to neonates undergoing cooling for encephalopathy (DANCE) trial if they were $\geq 36 \mathrm{wk}$ gestation by best obstetric estimate, were $<12 \mathrm{~h}$, had evidence of moderate-severe acute neonatal HIE as defined by Shankaran et al. (5), and had received hypothermia by $6 \mathrm{~h}$ after birth. Physiologic eligibility criteria for the DANCE trial were similar to the criteria currently used for initiating hypothermia: severe fetal or early $(<1 \mathrm{~h}$ age $)$ neonatal acidosis defined as arterial $\mathrm{pH} \leq 7.0$ or a base deficit $\geq 16 \mathrm{~m} \mathrm{mEq} / \mathrm{l}$. If a blood gas was not available or a blood gas at $\leq 1 \mathrm{~h}$ of age had a $\mathrm{pH}$ between 7.01 and 7.15 , or a base deficit was between 10 and $15.9 \mathrm{mEq} / \mathrm{l}$, additional criteria were required: (i) acute perinatal event AND, (ii) either a 10-min Apgar score $\leq 5$ or assisted ventilation initiated at birth and continued for at least $10 \mathrm{~min}$. Once these criteria were met, all infants underwent a standardized neurologic examination performed by the referring or receiving physician. The examination was recorded as soon as the patient met criteria for initiating hypothermia. Infants were eligible for the trial if moderate or severe encephalopathy-and/or seizures-were present. Moderate or severe encephalopathy was defined as the presence of one or more signs in at least three of the six categories: (i) altered level of consciousness; (ii) decreased or no activity; (iii) abnormal posture with distal flexion, complete extension or decerebration; (iv) hypotonia or hypertonia; (v) abnormal primitive reflexes with absent or weak suck and/or absent or incomplete Moro; and (vi) altered autonomic system signs such as constricted, deviated, dilated or nonreactive pupils; bradycardia; periodic breathing or apnea.

Exclusion criteria included major congenital and/or chromosomal abnormalities, prenatal diagnosis of brain abnormality or hydrocephalus, severe growth restriction $(\leq 1,800 \mathrm{~g})$, central venous hematocrit $>65 \%$, platelet count $>600,000 / \mathrm{dl}$, and/or neutropenia (absolute neutrophil count $<500 / \mu l$ ), maternal history of major vascular thrombosis or multiple fetal losses ( $\geq 3$ spontaneous abortions), extracorporeal membrane oxygenation (ECMO), and/or if the infant was judged critically ill and unlikely to benefit from intensive care by the attending neonatologist.

\section{Study Arms and Study Drug administration}

Following informed consent, study subjects were randomized to receive either Darbe (Aranesp, Amgen, Thousand Oaks, CA) low dose $(2 \mu \mathrm{g} / \mathrm{kg}$ IV); Darbe high dose $(10 \mu \mathrm{g} / \mathrm{kg}$ IV); or placebo (normal saline). Assignment to a treatment group was done randomly using a centralized computer randomization website (The University of Utah Data Coordinating and Analysis Center, Salt Lake City, UT). Treatment was blinded to all caregivers. All groups received the first study drug dose as soon as possible after cooling was initiated and no later than $12 \mathrm{~h}$ of life. All patients completed $72 \mathrm{~h}$ of hypothermia after which they were rewarmed as per each site therapeutic hypothermia protocol. A second study dose was administered at $7 \mathrm{~d}$ of life (normothermia condition). Study drug was administered over 5 min intravenously (IV), followed by a normal saline flush. Criteria for withholding the study drug included neutropenia $(\mathrm{ANC}<500 / \mu \mathrm{l})$, polycythemia (hematocrit of $>65 \%$ ), stroke, symptomatic clot, or 
hypertension (blood pressure $2 \mathrm{SD}$ greater than the mean for age). We considered Darbe well tolerated if there were no serious side effects or need to withhold the study drug.

\section{Safety}

Serious adverse events (SAE) included major venous thromboses, stroke, serious bleeding, severe hypertension, and/or death. SAEs were monitored until $30 \mathrm{~d}$ following the second study dose. Adverse events (AEs) were recorded during the first $14 \mathrm{~d}$ of life and included alterations in blood pressure, secondary infections, neutropenia, thrombotic/vascular events, polycythemia, hepatic/renal function that were outside of the normal range for the study population, and any change in the infant's condition requiring a new treatment. Altered renal function was defined as urine output $<0.5 \mathrm{ml} / \mathrm{kg} / \mathrm{h}$ for $>24 \mathrm{~h}$ or serum creatinine $>1.5 \mathrm{mg} / \mathrm{dl}$. Altered hepatic function was defined as aspartate aminotransferase (AST) $>200 \mathrm{IU} / \mathrm{l}$ and/ or alanine aminotransferase (ALT) $>100$ IU/l. Hypotension was defined as systolic blood pressure $\leq 50 \mathrm{mmHg}$ requiring inotrope support. The above SAEs and AEs were agreed upon by the investigators based on the most common adverse events reported for ESAs and the most common comorbidities observed in this patient population.

A DSMB performed an interim safety analysis after 10 infants were enrolled and every 6 mo thereafter.

Data were collected from clinical laboratory studies routinely assessed in infants undergoing cooling including: liver and renal function, hematocrit level, white cell count, platelet count, prothrombin time, partial thromboplastin, fibrinogen, and d-dimer.

\section{Neuroimaging}

Brain MRI scans performed as part of routine clinical care were deidentified and transmitted to Washington University, Saint Louis, where Dr. Robert McKinstry (Director of Neuroimaging Core) provided centralized interpretation using a validated, standardized scoring system (35). The scoring system involved separately measuring the severity of injury (range $1-4$, with $1=$ normal and $4=$ severe) in the right and left white matter, basal ganglia, cortex, brainstem, and cerebellum. These component scores were summed to give a global injury score. The global injury score was rated as follows: "none" $=48$; "mild" = 49-59; "moderate" = 60-80; "severe" = >81.

\section{Pharmacokinetic Analysis}

Serum, urine, and CSF levels were obtained for measurement of Darbe concentrations ( $0.2 \mathrm{ml}$ plasma, $1-2 \mathrm{ml}$ urine, and $0.2 \mathrm{ml} \mathrm{CSF}$ ) and analyzed using a Quantikine IVD human Epo Immunoassay ELISA (R\&D Systems, Minneapolis, MN) as previously described $(25,27)$. To avoid excessive phlebotomy losses, sparse sampling was utilized in this this study: serum was obtained from odd-numbered infants prior to administration of drug (baseline), at 4, 12, 24, and $60 \mathrm{~h}$, or from even-numbered patients at baseline, $4,18,36$, and $72 \mathrm{~h}$, postadministration of the first study dose. Following the second dose, serum samples were obtained at 12 and $24 \mathrm{~h}$ (odd-numbered patients) or at 18 and $36 \mathrm{~h}$ (even-numbered patients). The profiles from both groups were then used together in a population method to determine the full pharmacokinetic profile of Darbe. Urine was collected every $6 \mathrm{~h}$ during the first $24 \mathrm{~h}$ of life. Lastly, CSF was obtained only in the event that a spinal tap was clinically indicated. A blood sample for measurement of Darbe was also obtained within $15 \mathrm{~min}$ of the collection of CSF to assess the CSF: plasma ratio.

\section{Quantification of Samples}

A weighted $\left(1 / \mathrm{x}^{2}\right)$ quadratic regression model was fitted to each standard curve. Each individual sample well was quantified by interpolation, after which, duplicates were averaged. If samples were evaluated on more than $1 \mathrm{~d}$, all wells were averaged for the final sample quantitation. Duplicates in the standard curve that had an intraday coefficient of variation $>0.10$ or samples that had intra- or interday coefficient of variations $>0.10$ were excluded from the analysis. In addition, standards that did not meet FDA guidelines $( \pm 20 \%$ for the lower limit of quantitation, $\pm 15 \%$ for all others) were not included in the standard curve.

\section{Pharmacokinetic Modeling and Statistical Analysis}

A noncompartmental approach using Phoenix WinNonLin, version 5.1 (Pharsight, Mountain View, CA) and R 3.0.2 (R Foundation for Statistical Computing, Vienna, Austria) was used to estimate Darbe pharmacokinetic parameters. The median Epo concentration from the placebo group at each time point was subtracted from each Darbe treated patient to isolate the fraction of the erythropoietin concentration that was attributable to the administration of Darbe. The area under the concentration-time curve extrapolated to infinity $\left(\mathrm{AUC}_{\text {inf }}\right)$ (calculated using the log-linear trapezoidal method), the half-life $\left(t_{1 / 2}\right)$, and the mean residence time for the Darbe treatment groups were estimated for the first and second doses. The maximum plasma concentration $\left(C_{\max }\right)$ and clearance $(\mathrm{CL})$ were only determined for the first dose due to limited sampling times following the second dose. The area under the urinary excretion rate curve from $0-24 \mathrm{~h}$ (AURC ${ }_{24}$ ) was determined for each treatment group for the first dose. The Wilcoxon rank-sum test was used to compare Darbe pharmacokinetics between the treatment groups. A $P$ value of $\leq 0.05$ was considered significant.

\section{ACKNOWLEDGMENTS}

The authors thank the work of the Data Safety Monitoring Board: Donald McCurnin, MD (Chair), Richard Holubkov, PhD, Sarah Winter, MD, and Francis Filloux, MD. The authors thank Alfred Balch, PhD (CCTS) for his assistance with the statistical analysis. We also thank all neonatal research nurses and clinical coordinators in all centers, in particular Karen Osborne and Cindy Spencer for their assistance in the creation of the case report forms and manual of operation. Study data were entered in RedCap at the University of Utah (Center for Clinical and Translational Sciences). The randomization website was supported by Rene Enriquez (IT Department Pediatrics Critical Care, University of Utah).

\section{STATEMENT OF FINANCIAL SUPPORT}

This study was supported by Thrasher Research Fund (Salt Lake City, UT) through an E.W. “AL"Thrasher Award to M.C.Baserga-(10026771-F1).

Disclosures: M.C.B. and the coauthors have no financial ties to products in the study and no potential/perceived conflict of interest.

\section{REFERENCES}

1. Graham EM, Ruis KA, Hartman AL, Northington FJ, Fox HE. A systematic review of the role of intrapartum hypoxia-ischemia in the causation of neonatal encephalopathy. Am J Obstet Gynecol 2008;199:587-95.

2. Liu L, Oza S, Hogan D, et al. Global, regional, and national causes of child mortality in $2000-13$, with projections to inform post- 2015 priorities: an updated systematic analysis. Lancet 2014;385:430-40.

3. Shankaran S, Woldt E, Koepke T, Bedard MP, Nandyal R. Acute neonatal morbidity and long-term central nervous system sequelae of perinatal asphyxia in term infants. Early Hum Dev 1991;25:135-48.

4. Robertson CM, Finer NN, Grace MG. School performance of survivors of neonatal encephalopathy associated with birth asphyxia at term. J Pediatr 1989;114:753-60.

5. Shankaran S, Laptook AR, Ehrenkranz RA, et al.; National Institute of Child Health and Human Development Neonatal Research Network. Whole-body hypothermia for neonates with hypoxic-ischemic encephalopathy. N Engl J Med 2005;353:1574-84.

6. Tagin MA, Woolcott CG, Vincer MJ, Whyte RK, Stinson DA. Hypothermia for neonatal hypoxic ischemic encephalopathy: an updated systematic review and meta-analysis. Arch Pediatr Adolesc Med 2012;166:558-66.

7. Cotten CM, Shankaran S. Hypothermia for hypoxic-ischemic encephalopathy. Expert Rev Obstet Gynecol 2010;5:227-39.

8. Grasso G, Graziano F, Sfacteria A, et al. Neuroprotective effect of erythropoietin and darbepoetin alfa after experimental intracerebral hemorrhage. Neurosurgery 2009;65:763-9; discussion 769-70.

9. Traudt CM, McPherson RJ, Bauer LA, et al. Concurrent erythropoietin and hypothermia treatment improve outcomes in a term nonhuman primate model of perinatal asphyxia. Dev Neurosci 2013;35:491-503.

10. Sirén AL, Fratelli M, Brines M, et al. Erythropoietin prevents neuronal apoptosis after cerebral ischemia and metabolic stress. Proc Natl Acad Sci USA 2001;98:4044-9. 
11. Grasso G, Buemi M, Alafaci C, et al. Beneficial effects of systemic administration of recombinant human erythropoietin in rabbits subjected to subarachnoid hemorrhage. Proc Natl Acad Sci USA 2002;99:5627-31.

12. Demers EJ, McPherson RJ, Juul SE. Erythropoietin protects dopaminergic neurons and improves neurobehavioral outcomes in juvenile rats after neonatal hypoxia-ischemia. Pediatr Res 2005;58:297-301.

13. Zhu C, Kang W, Xu F, et al. Erythropoietin improved neurologic outcomes in newborns with hypoxic-ischemic encephalopathy. Pediatrics 2009;124:e218-26.

14. Elmahdy H, El-Mashad AR, El-Bahrawy H, El-Gohary T, El-Barbary A, Aly H. Human recombinant erythropoietin in asphyxia neonatorum: pilot trial. Pediatrics 2010;125:e1135-42.

15. Warwood TL, Ohls RK, Wiedmeier SE, et al. Single-dose darbepoetin administration to anemic preterm neonates. J Perinatol 2005;25:725-30.

16. Ohls RK, Kamath-Rayne BD, Christensen RD, et al. Cognitive outcomes of preterm infants randomized to darbepoetin, erythropoietin, or placebo. Pediatrics 2014;133:1023-30.

17. Juul SE, Anderson DK, Li Y, Christensen RD. Erythropoietin and erythropoietin receptor in the developing human central nervous system. Pediatr Res 1998;43:40-9.

18. Hasselblatt M, Ehrenreich H, Sirén AL. The brain erythropoietin system and its potential for therapeutic exploitation in brain disease. J Neurosurg Anesthesiol 2006;18:132-8.

19. Banks WA, Jumbe NL, Farrell CL, Niehoff ML, Heatherington AC. Passage of erythropoietic agents across the blood-brain barrier: a comparison of human and murine erythropoietin and the analog darbepoetin alfa. Eur J Pharmacol 2004;505:93-101.

20. Wen TC, Sadamoto Y, Tanaka J, et al. Erythropoietin protects neurons against chemical hypoxia and cerebral ischemic injury by up-regulating Bcl-xL expression. J Neurosci Res 2002;67:795-803.

21. Iwai M, Cao G, Yin W, Stetler RA, Liu J, Chen J. Erythropoietin promotes neuronal replacement through revascularization and neurogenesis after neonatal hypoxia/ischemia in rats. Stroke 2007;38:2795-803.

22. Cherian L, Goodman JC, Robertson C. Improved cerebrovascular function and reduced histological damage with darbepoietin alfa administration after cortical impact injury in rats. J Pharmacol Exp Ther 2011;337:451-6.

23. Belayev L, Khoutorova L, Zhao W, et al. Neuroprotective effect of darbepoetin alfa, a novel recombinant erythropoietic protein, in focal cerebral ischemia in rats. Stroke 2005;36:1071-6.
24. Juul SE, McPherson RJ, Bauer LA, Ledbetter KJ, Gleason CA, Mayock DE. A phase I/II trial of high-dose erythropoietin in extremely low birth weight infants: pharmacokinetics and safety. Pediatrics 2008;122:383-91.

25. Wu YW, Bauer LA, Ballard RA, et al. Erythropoietin for neuroprotection in neonatal encephalopathy: safety and pharmacokinetics. Pediatrics 2012;130:683-91.

26. Macdougall IC, Gray SJ, Elston O, et al. Pharmacokinetics of novel erythropoiesis stimulating protein compared with epoetin alfa in dialysis patients. J Am Soc Nephrol 1999;10:2392-5.

27. Warwood TL, Ohls RK, Lambert DK, et al. Intravenous administration of darbepoetin to NICU patients. J Perinatol 2006;26:296-300.

28. Widness JA, Veng-Pedersen P, Modi NB, Schmidt RL, Chestnut DH. Developmental differences in erythropoietin pharmacokinetics: increased clearance and distribution in fetal and neonatal sheep. J Pharmacol Exp Ther 1992;261:977-84.

29. Chapel S, Veng-Pedersen P, Hohl RJ, Schmidt RL, McGuire EM, Widness JA. Changes in erythropoietin pharmacokinetics following busulfan-induced bone marrow ablation in sheep: evidence for bone marrow as a major erythropoietin elimination pathway. J Pharmacol Exp Ther 2001;298:820-4.

30. Freise KJ, Widness JA, Segar JL, Schmidt RL, Veng-Pedersen P. Increased erythropoietin elimination in fetal sheep following chronic phlebotomy. Pharm Res 2007;24:1653-9.

31. STOHLMAN F Jr, BRECHER G. Humoral regulation of erythropoiesis. V. Relationship of plasma erythropoietine level to bone marrow activity. Proc Soc Exp Biol Med 1959;100:40-3.

32. Jelkmann $\mathrm{W}$. The enigma of the metabolic fate of circulating erythropoietin (Epo) in view of the pharmacokinetics of the recombinant drugs rhEpo and NESP. Eur J Haematol 2002;69:265-74.

33. Warwood TL, Ohls RK, Lambert DK, Leve EA, Veng-Pedersen P, Christensen RD. Urinary excretion of darbepoetin after intravenous vs subcutaneous administration to preterm neonates. J Perinatol 2006;26:636-9.

34. Statler PA, McPherson RJ, Bauer LA, Kellert BA, Juul SE. Pharmacokinetics of high-dose recombinant erythropoietin in plasma and brain of neonatal rats. Pediatr Res 2007;61:671-5.

35. Cheong JL, Coleman L, Hunt RW, et al.; Infant Cooling Evaluation Collaboration. Prognostic utility of magnetic resonance imaging in neonatal hypoxic-ischemic encephalopathy: substudy of a randomized trial. Arch Pediatr Adolesc Med 2012;166:634-40. 